\title{
Survival protein anoctamin-6 controls multiple platelet responses including phospholipid scrambling, swelling, and protein cleavage
}

Citation for published version (APA):

Mattheij, N. J. A., Braun, A., van Kruchten, R., Castoldi, E., Pircher, J., Baaten, C. C. F. M. J., Wuelling, M., Kuijpers, M. J. E., Koehler, R., Poole, A. W., Schreiber, R., Vortkamp, A., Collins, P. W., Nieswandt, B., Kunzelmann, K., Cosemans, J. M. E. M., \& Heemskerk, J. W. M. (2016). Survival protein anoctamin-6 controls multiple platelet responses including phospholipid scrambling, swelling, and protein cleavage. Faseb Journal, 30(2), 727-737. https://doi.org/10.1096/fj.15-280446

Document status and date:

Published: 01/02/2016

DOI:

10.1096/fj.15-280446

Document Version:

Publisher's PDF, also known as Version of record

\section{Document license:}

Taverne

Please check the document version of this publication:

- A submitted manuscript is the version of the article upon submission and before peer-review. There can be important differences between the submitted version and the official published version of record.

People interested in the research are advised to contact the author for the final version of the publication, or visit the DOI to the publisher's website.

- The final author version and the galley proof are versions of the publication after peer review.

- The final published version features the final layout of the paper including the volume, issue and page numbers.

Link to publication

\footnotetext{
General rights rights.

- You may freely distribute the URL identifying the publication in the public portal. please follow below link for the End User Agreement:

www.umlib.nl/taverne-license

Take down policy

If you believe that this document breaches copyright please contact us at:

repository@maastrichtuniversity.nl

providing details and we will investigate your claim.
}

Copyright and moral rights for the publications made accessible in the public portal are retained by the authors and/or other copyright owners and it is a condition of accessing publications that users recognise and abide by the legal requirements associated with these

- Users may download and print one copy of any publication from the public portal for the purpose of private study or research.

- You may not further distribute the material or use it for any profit-making activity or commercial gain

If the publication is distributed under the terms of Article 25fa of the Dutch Copyright Act, indicated by the "Taverne" license above, 


\section{Vaccine Discovery and Development: Lessons from COVID-19}

\section{Free eBook}

Emerging infectious diseases (EIDs) can evolve into a global healthcare crisis or pandemic. Scientists have previously required years to develop vaccines or therapeutics. The use of high throughput technology can greatly broaden the insights collected during discovery, augment efficiency and safety of handling EIDs, and shorten timelines.

Download this publication for an overview of many lessons learned in virology, immunology, and vaccine research during COVID-19 vaccine development.

\section{Download here}




\title{
Survival protein anoctamin-6 controls multiple platelet responses including phospholipid scrambling, swelling, and protein cleavage
}

\author{
Nadine J. A. Mattheij, ${ }^{*}$ Attila Braun, ${ }^{\dagger}$ Roger van Kruchten,* Elisabetta Castoldi,* \\ Joachim Pircher, ${ }^{\ddagger}$ Constance C. F. M. J. Baaten, ${ }^{*}$ Manuela Wülling, ${ }^{\S}$ Marijke J. E. Kuijpers, ${ }^{*}$ \\ Ralf Köhler, ${ }^{\top}$ Alastair W. Poole, ${ }^{\|}$Rainer Schreiber, ${ }^{\#}$ Andrea Vortkamp, ${ }^{\S}$ Peter W. Collins, ${ }^{* *}$ \\ Bernhard Nieswandt, ${ }^{\dagger}$ Karl Kunzelmann, ${ }^{\#}$ Judith M. E. M Cosemans, ${ }^{*}$ \\ and Johan W. M. Heemskerk*,1 \\ *Department of Cell Biochemistry of Thrombosis and Haemostasis Biochemistry, Cardiovascular \\ Research Institute Maastricht (CARIM), University of Maastricht, Maastricht, The Netherlands; \\ ${ }^{\dagger}$ Department of Experimental Biomedicine, University Hospital and Rudolf Virchow Center, University \\ of Würzburg, Würzburg, Germany; ${ }^{\dagger}$ Walter Brendel Centre of Experimental Medicine and German \\ Centre of Cardiovascular Research, Munich Heart Alliance, Ludwig-Maximilians-Universität München, \\ München, Germany; "Department of Developmental Biology, Centre for Medical Biotechnology, \\ University of Duisburg-Essen, Duisburg-Essen, Germany; ${ }^{\circledR}$ Aragon Institute of Health Sciences I+CS/IIS \\ and ARAID, Zaragoza, Spain; "School of Physiology and Pharmacology, University of Bristol, Bristol, \\ United Kingdom; "Institute of Physiology, University of Regensburg, Regensburg, Germany; **Arthur \\ Bloom Haemophilia Centre, School of Medicine, Cardiff University, Cardiff, United Kingdom
}

ABSTRACT Scott syndrome is a rare bleeding disorder, characterized by altered $\mathrm{Ca}^{2+}$-dependent platelet signaling with defective phosphatidylserine (PS) exposure and microparticle formation, and is linked to mutations in the ANO6 gene, encoding anoctamin (Ano)6. We investigated how the complex platelet phenotype of this syndrome is linked to defective expression of Anos or other ion channels. Mice were generated with heterozygous of homozygous deficiency in Ano6, Ano1, or $\mathrm{Ca}^{2+}$-dependent $\mathrm{K}_{\mathrm{Ca}} 3.1$ Gardos channel. Platelets from these mice were extensively analyzed on molecular functions and compared with platelets from a patient with Scott syndrome. Deficiency in Ano1 or Gardos channel did not reduce platelet responses compared with control mice $(P>0.1)$. In 2 mouse strains, deficiency in Ano6 resulted in reduced viability with increased bleeding time to $28.6 \mathrm{~min}$ (control $6.4 \mathrm{~min}, P<0.05$ ). Platelets from the surviving Ano6-deficient mice resembled platelets from patients with Scott syndrome in: 1) normal collageninduced aggregate formation $(P>0.05)$ with reduced PS exposure (-65 to $90 \%) ; 2$ ) lowered $\mathrm{Ca}^{2+}$-dependent swelling $(-80 \%)$ and membrane blebbing $(-90 \%) ; 3)$ reduced calpain-dependent protein cleavage $(-60 \%)$; and 4$)$ moderately affected apoptosis-dependent PS exposure. In conclusion, mouse deficiency of Ano6 but not of other channels affects viability and phenocopies the complex changes in platelets from hemostatically impaired patients with Scott syndrome.-Mattheij, N. J. A., Braun, A., van Kruchten, R., Castoldi, E., Pircher, J., Baaten, C. C. F. M. J., Wülling, M.,

Abbreviations: AF647, Alexa Fluor 647; Ano, anoctamin; GPVI, glycoprotein VI; PE, phycoerythrin; PRP, platelet-rich plasma; PS, phosphatidylserine
Kuijpers, M. J. E., Köhler, R., Poole, A. W., Schreiber, R., Vortkamp, A., Collins, P. W., Nieswandt, B., Kunzelmann, K., Cosemans, J. M. E. M., Heemskerk, J. W. M. Survival protein anoctamin-6 controls multiple platelet responses including phospholipid scrambling, swelling, and protein cleavage. FASEB J. 30, 727-737 (2016). www.fasebj.org

Key Words: bleeding • embryonic lethality • phosphatidylserine • Scott syndrome $\cdot$ TMEM16F

The uncommon Scott syndrome is characterized as a mild bleeding disorder associated with low prothrombin consumption in blood serum. Platelets from patients with Scott syndrome show a defect in $\mathrm{Ca}^{2+}$-induced phosphatidylserine (PS) exposure and microparticle formation, but unchanged $\mathrm{Ca}^{2+}$ signaling and aggregation (1-4). It has long been recognized that the defective PS exposure in blood cells from patients with Scott syndrome results from impaired phospholipid scrambling, a process that normally abolishes the asymmetric distribution of PS and phosphatidylethanolamine over the plasma membrane upon persistent elevation of cytosolic $\mathrm{Ca}^{2+}(5-7)$. A consequence of the defective PS exposure is a markedly impaired procoagulant activity of platelets, which agrees with the bleeding phenotype (8). On the other hand, PS exposure induced

\footnotetext{
${ }^{1}$ Correspondence: Chair of Cell Biochemistry of Thrombosis and Haemostasis Biochemistry, CARIM, Maastricht University PO Box 616, 6200 MD, Maastricht, The Netherlands. E-mail: jwm.heemskerk@maastrichtuniversity.nl

doi: 10.1096/fj.15-280446

This article includes supplemental data. Please visit http:// www. fasebj.org to obtain this information.
} 
by apoptosis (9) is little affected in the blood cells from patients with Scott syndrome $(10,11)$.

Recently, in 2 unrelated patients with Scott syndrome, dysfunctional mutations have been identified in the ANOG gene (alternatively named TMEM16F), which codes for the integral membrane protein anoctamin (Ano) $6(12,13)$. In a murine B-cell line model, the silencing of Ano6 resulted in an impairment of $\mathrm{Ca}^{2+}$-dependent PS exposure (12). A role of Anos as transporters for the negatively charged PS was also confirmed by structural analysis (14). In addition, there is substantial electrophysiological evidence that Ano6, like other members of the Ano family, can operate as a $\mathrm{Ca}^{2+}$-induced ion channel that is permeable to chloride ions, monovalent cations, and calcium ions $(10,15-17)$. We and others have reported that in blood cells from patients with Scott syndrome (10) and Ano6-deficient mice (17), this ion conductance is markedly reduced. Hence, the question arises which other (patho) physiological relevant functions are regulated by Ano6 rather than only $\mathrm{Ca}^{2+}$ dependent phospholipid scrambling. Several observations in the literature are compatible with a broader role of Ano6. For instance, platelets from patients with Scott syndrome show reduced $\mathrm{Ca}^{2+}$-dependent microvesiculation $(1,3)$, impaired inactivation of the integrin $\alpha_{\text {IIb }} \beta_{3}$ (18), and defective aging-dependent PS exposure (19).

On the other hand, Scott platelets are not completely devoid of PS exposure and procoagulant activity, when stimulated with $\mathrm{Ca}^{2+}$-mobilizing agonists such as thrombin plus collagen $(6,11)$. This suggests involvement of other proteins besides Ano6 in the regulation of $\mathrm{Ca}^{2+}$-induced phospholipid scrambling. In platelets as well as erythrocytes, a role in PS exposure of has been proposed for volumesensitive $\mathrm{Cl}^{-}$channels (20) and for intermediate conductance $\mathrm{Ca}^{2+}$-activated $\mathrm{K}^{+}$channels, known as $\mathrm{K}_{\mathrm{Ca}} 3.1$ or Gardos channels $(21,22)$. Furthermore, overexpression studies suggest that also other members of the Ano family can contribute to PS exposure (23). In particular, the isoform Anol is of interest, because in erythrocytes it regulates $\alpha$-hemolysininduced phospholipid scrambling (24). Hence, the question can be raised if a gene defect in ANO6 alone is sufficient for the altered blood cell properties in the Scott syndrome.

In the present study, we used several molecular and functional approaches to unravel the apparently multiple and nonredundant functions of Ano6 in platelets and erythrocytes. We compared the alterations in platelet properties of a patient with Scott syndrome with platelets from healthy control subjects and furthermore compared the platelet properties of several new strains of Ano6-deficient mice, as well as from mice lacking Ano1 or Gardos channels. Our data point to a remarkable set of phenotypic changes linked to defective Ano6 expression in both humans and mice, including low residual $\mathrm{Ca}^{2+}$-dependent PS exposure, absence of swelling morphologic changes, presence of alternative Ano6 splice variants, and a moderate bleeding tendency.

\section{MATERIALS AND METHODS}

\section{Materials}

ABT-737 was obtained from Santa Cruz Biotechnology (Santa Cruz, CA, USA), annexin A5 labeled with FITC was from PharmaTarget (Maastricht, The Netherlands); Alexa Fluor 647
(AF647)-labeled annexin A5 and ionomycin were purchased from Invitrogen (Carlsbad, CA, USA). The glycoprotein VI (GPVI) agonist convulxin was purified, as described previously (25). FITC-labeled anti-mouse CD62P (P-selectin) mAb as well as phycoerythrin (PE)-conjugated JON/A mAb directed against the active conformation of mouse integrin $\alpha_{\text {IIb }} \beta_{3}$ were from Emfret Analytics (Würzburg, Germany). Human $\alpha$-thrombin was from Sigma-Aldrich (St. Louis, MO, USA). Affinity-purified polyclonal rabbit antibodies directed against human and mouse Anol (DOG-1) and Ano6 (G-14 against extracellular domain) were from Santa Cruz, anti- $\alpha$-tubulin mAb came from Abcam (Cambridge, MA, USA). Rabbit antibody directed against mouse $\mathrm{K}_{\mathrm{Ca}} 3.1$ was obtained as described previously (26). Sources of other materials were as reported elsewhere (18).

\section{Blood donors}

Blood was obtained from healthy volunteers and an accessible patient with Scott syndrome, after full informed consent (Helsinki declaration), under protocols reviewed by the local ethics committees. The patients with Scott syndrome have been genotyped as compound heterozygous for 2 different mutations in the ANO6 gene (alias TMEM1GF), with 1 splicing mutation (IVS6 + $1 \mathrm{G} \rightarrow \mathrm{A}$ ) causing exon 6 skipping, and another mutation in exon 11 (c.1219insT) leading to a premature stop of translation (13). An analysis of splice variants is described in the supplemental materials (Supplemental Fig. S1).

\section{Animals}

Mouse experiments were approved by the local animal care and use committees. Experiments were performed using genetically modified and corresponding wild-type animals from the same breeding, simultaneously at the same location. Mice with a homozygous deficiency of the Gardos channel $\mathrm{K}_{\mathrm{Ca}} 3.1\left(\mathrm{Kcnn}^{-/-}\right)$ and wild-type littermates $\left(\mathrm{Kcnn}^{+/+}\right)$had a mixed 129Sv/C57BL/ 6 background and were generated and genotyped as described elsewhere (27). Homozygous Kcnn $4^{-/}$mice suffer from hypertension, but survive normally $(27,28)$. Mice with megakaryocytes and platelets homozygously deficient in Anol (Anol gene, alias Tmem 16a) were generated by crossing $A n o 1^{\mathrm{fl} / \mathrm{fl}}$ mice with transgenic mice expressing a Cre-recombinase after the PF4 promoter (C57BL/6 background). The mice were genotyped using the following nucleotide primers: wild-type $\mathrm{Anol}^{+/+}$(229 bp, $2165 \mathrm{bp}$ in flox) GCAGAAAAGT GCCAGAGACC (forward), TTTCCAATGG CCTAGACCTG (reverse); for $A_{n o 1^{-1}}$ (462 bp in flox) ATAGCAGCTT TGCTCCTTCG (forward), CTCGTCCTGC AGTTCATTCA (reverse).

In 2 laboratories (Würzburg, Regensburg), the AW-382 embryonic stem cell clone $A n o 6^{\text {gt(AW0382) }}$ ( $A n o 6^{A W}$; Wellcome Trust Sanger Institute; Mouse Genome Informatics: 3857206, stock number 020701-UCD) was used to generate mice with genetic deficiency of Ano6 (alias Tmem16f). The embryonic stem cell clone contains a $\beta$-geo reporter gene trap in intron 3 of Ano6, which disturbs mRNA transcription and synthesis of the protein. Male chimeras derived from the embryonic stem cell line were bred with C57BL/ 6 females to generate heterozygous $A n o 6^{A W_{+} /-}$mice. The latter were cross-bred at C57BL/ 6 background to obtain homozygous deficient mice. Presence of the gene trap cassette was detected by PCR using the following primers: TTATCGATGA GCGTGGTGGT TATGC (forward); GCGCGTACAT CGGGCAAATA ATATC (reverse).

In addition, mice from the $A n o 6^{\text {tm1Avor }}\left(A n o 6^{A v o r}\right)$ strain were used, generated as described elsewhere (29). To reduce postnatal lethality of homozygous mutants, Ano $6^{\text {Avort } /-}$ mice were crossed on a C57B6L background to obtain Ano6 $6^{\text {Avor- } /-}$ animals. Mice were genotyped for heterozygous or homozygous deficiency in 
Ano6 expression by PCR (29). Per strain, wild-types were used from the same breeding. Analysis of murine Ano6 splice variants is described in (Supplemental Fig. S4).

\section{Embryonic development}

Inbred, pregnant female $A n o \sigma^{+/-}$mice were killed at gestational d 10.5, 12.5, or 16.5. Viable embryos and death bodies were counted, and embryos were checked for macroscopic abnormalities.

\section{Blood collection and isolation of platelets and erythrocytes}

Human blood was collected into PPACK/fragmin for flow perfusion studies, as described previously (30). Other samples were collected into trisodium citrate for preparation of platelet-rich plasma (PRP) (31) or into acid-citrate-dextrose anticoagulant for preparation of isolated platelets (18). Washed cells were suspended into HEPES buffer pH 7.45 (10 mM HEPES, $136 \mathrm{mM}$ $\mathrm{NaCl}, 2.7 \mathrm{mM} \mathrm{KCl}, 2 \mathrm{mM} \mathrm{MgCl}_{2}, 5 \mathrm{mM}$ glucose, and $0.1 \%$ bovine serum albumin); $2 \mathrm{mM} \mathrm{CaCl}_{2}$ was added directly before the experiments. Cell concentrations were determined with a Beckman Coulter (Brea, CA, USA) counter.

Blood was obtained from adult mice via orbital puncture under anesthesia, according to the local ethical permissions. Mouse blood was collected into PPACK/heparin/fragmin for flow perfusion studies, as described elsewhere (32). Blood was also collected into trisodium citrate for preparation of PRP (18). For platelet isolation, mouse blood was taken into $1 / 6$ volume of acidcitrate-dextrose anticoagulant $(85 \mathrm{mM}$ sodium citrate, $78 \mathrm{mM}$ citric acid, and $11 \mathrm{mM}$ D-glucose). Platelets (18) and erythrocytes (22) were separated by centrifugation, washed, and suspended in modified HEPES buffer pH 7.45 (5 mM HEPES, $136 \mathrm{mM} \mathrm{NaCl}$, $2.7 \mathrm{mM} \mathrm{KCl}, 2 \mathrm{mM} \mathrm{MgCl}_{2}, 0.42 \mathrm{mM} \mathrm{Na}_{2} \mathrm{HPO}_{4}, 5 \mathrm{mM}$ glucose, and $0.1 \%$ bovine serum albumin); $2 \mathrm{mM} \mathrm{CaCl}_{2}$ was added directly before the experiments. Cell concentrations were determined with a Coulter counter.

\section{Flow cytometric analyses}

Suspensions of washed human platelets were activated, as described elsewhere (11). Washed mouse platelets in suspension $\left(1 \times 10^{11} / \mathrm{L}\right)$ were stimulated in the presence of $2 \mathrm{mM} \mathrm{CaCl}_{2}$ with indicated agonists or vehicle at room temperature. Platelet samples were analyzed for PS after 30 min of activation and labeling with AF647-annexin A5 (1:200) (18). Other labels used were FITC-anti-P-selectin mAb (1:10) to detect P-selectin expression and PE-JON/A mAb (1:10) to detect integrin $\alpha_{\mathrm{IIb}} \beta_{3}$ activation. For apoptosis induction, platelets were stimulated with the $\mathrm{BH} 3$ mimetic ABT-737 $(1 \mu \mathrm{M})$ for $1 \mathrm{~h}$ at $37^{\circ} \mathrm{C}(18)$. Washed mouse erythrocytes $\left(1 \times 10^{11} / \mathrm{L}\right)$ were activated with ionomycin in the presence of $1 \mathrm{mM} \mathrm{CaCl}_{2}$ at $37^{\circ} \mathrm{C}$. Samples were analyzed with a BD Facs Calibur or BD Accuri C6 flow cytometer (Becton Dickinson, San Diego, CA, USA). Glycoprotein expression levels on platelets were determined by flow cytometry as described elsewhere (33). Data analysis was performed using the programs WinMDI (Becton Dickinson) or CFlow Plus (Becton Dickinson).

\section{Light transmission measurements}

Changes in light transmission were monitored in suspensions of washed platelets $\left(1 \times 10^{11} / \mathrm{L}\right)$, activated with agonists in the presence of $\mathrm{CaCl}_{2}(2 \mathrm{mM})$ under constant stirring at $37^{\circ} \mathrm{C}$, using a Chronolog (Havertown, PA, USA) optical aggregometer.
Tirofiban $(5 \mu \mathrm{g} / \mathrm{ml})$ was present if indicated. Hypotonic shock response (34) was induced by adding $125 \mu \mathrm{l}$ of distilled water with or without $\mathrm{CaCl}_{2}(4 \mathrm{mM})$ and/or ionomycin $(10 \mu \mathrm{M})$ to $250 \mu \mathrm{l}$ PRP. Transmission changes were recorded with the Chronolog aggregometer under stirring at $37^{\circ} \mathrm{C}$.

\section{Whole-blood thrombus formation}

Collagen-induced thrombus formation was assayed using PPACK/ fragmin-anticoagulated human (35) or mouse (36) blood, basically as described. In brief, blood samples were flowed over a coverslip coated with collagen type-I in a transparent parallelplate perfusion chamber, at a shear rate of $1000 \mathrm{~s}^{-1}$ for $4 \mathrm{~min}$. Thrombi formed on the collagen surface were poststained with AF647-annexin A5, FITC-anti-CD62P mAb, and PE-JON/A mAb in (modified) HEPES buffer pH 7.45 supplemented with $\mathrm{CaCl}_{2}$ $(2 \mathrm{mM})$ and heparin $(1 \mathrm{U} / \mathrm{ml})$. Phase-contrast and fluorescence images were captured for analysis of surface area coverage of adherent platelets and of platelets with active integrins, P-selectin exposure or PS exposure (30). Image analysis was performed using Metamorph software version 7.5.0.0 (MDS Analytical Technologies, Sunnyvale, CA, USA) (37).

\section{Western blot analyses}

Washed platelet or erythrocyte suspensions were lysed with ice-cold $4 \times$ lysis buffer $(600 \mathrm{mM} \mathrm{NaCl}, 10 \mathrm{mM}$ Tris, $4 \mathrm{mM}$ EGTA, $4 \mathrm{mM}$ EDTA, $4 \%$ NP40). Samples $\left(5 \times 10^{7}\right.$ human platelets, $1 \times 10^{8}$ mouse platelets) were separated on $8 \%$ SDS-PAGE gels, transferred to blotting membranes by semidry transfer (18). Membranes were immunostained with antibodies against $\mathrm{K}_{\mathrm{Ca}} 3.1$, Ano1, Ano6 (all 1:1000), or integrin $\beta_{3}(\mathrm{Ab} 762,1: 10000 ; \mathrm{Ab} 754,1: 1000)$, and later reprobed with $\alpha$-tubulin $(1: 1000)$. Incubation with secondary horseradish peroxidase-coupled antibody was overnight at $4^{\circ} \mathrm{C}$, and visualization with an ECL system. Quantification was performed by densitometric analysis of stained blots, as described (18).

\section{Statistics}

Intervention effects were statistically compared with a paired sample Student's $t$ test, using the statistical package for social sciences (SPSS, version 11.0; IBM SPSS, Chicago, IL, USA). Groups were compared by 2-way ANOVA (Bonferroni correction, if required).

\section{RESULTS}

\section{Residual PS exposure and abolished swelling of Scott platelets during thrombus formation}

Platelet aggregation and PS exposure (procoagulant activity) in response to the main collagen receptor, GPVI, can simultaneously be quantified in thrombi formed during whole-blood perfusion over a collagen surface $(35,38)$. In flow studies with blood from a patient with Scott syndrome (19), we established that platelet adhesion, aggregate formation, and $\alpha$-granule secretion (expression of P-selectin) were similar to the platelet responses of healthy control subjects (Fig. 1A, $\boldsymbol{B})$. In contrast, collagen-induced PS exposure was greatly reduced, but not completely abolished with the patient blood. Interestingly, the residual PS exposure appeared as patches on platelets with a normal, 

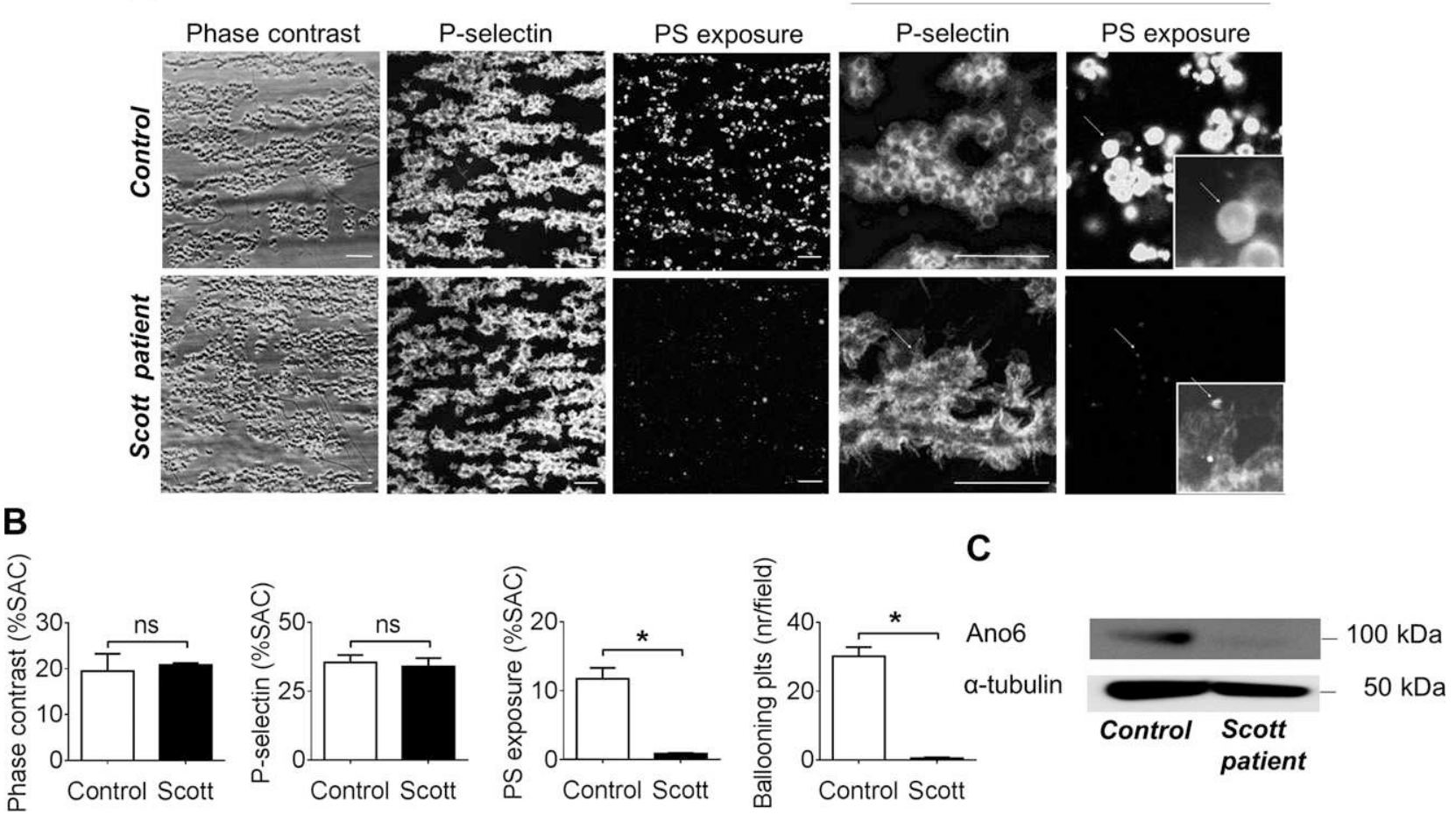

Figure 1. Normal thrombus formation with residual PS exposure and abolished ballooning in Scott syndrome. Blood from healthy control subjects or patients with Scott syndrome was perfused over a collagen surface for 4 min at $1000 \mathrm{~s}^{-1}$. Formed thrombi were stained with FITC- $\alpha$ CD62P (P-selectin) mAb and AF647-annexin A5 (PS exposure). A) Representative phasecontrast and fluorescence images (scale bars, $25 \mu \mathrm{m}$ ), zoomed in as indicated (insets, $25 \times 25 \mu \mathrm{m}$ ). Arrow (Scott) indicates nonballooning platelet with small patches of PS exposure. B) Surface area coverage (\%SAC) of aggregated platelets, P-selectin expression, PS exposure, and ballooning. For PS exposure, dotted line indicates background fluorescence (no platelet thrombi). $C$ ) Western blots of control and Scott platelet lysates, stained for Ano6, and reprobed with anti- $\alpha$-tubulin mAb as lane loading control. Means $\pm \mathrm{SE}(n=3) . * P<0.05$ (2-way ANOVA).

nonswollen shape (Fig. 1A, inserts). This contrasted with the large, ballooning morphology (diameter, $\sim 10 \mu \mathrm{m}$ ) of platelets from control subjects with high PS exposure. Quantification of the recorded microscopic images indicated that essentially no ballooning platelets were formed with Scott blood (Fig. 1A, right panel). Hence, the major defect of GPVI-dependent PS exposure in Scott platelets is accompanied by absence of platelet ballooning.

\section{Identification of human ANO6 splice variants}

An explanation for the low PS exposure in patient's platelets may be residual expression of the ANO6 gene. However, no Ano6 protein could be detected on Western blots from Scott platelets (Fig. 1C). This was confirmed by quantitative proteomic analysis (39), showing a $>160$-fold reduction of identified Ano6 peptides in the Scott platelets (unpublished results). On the other hand, in line with a previous report (13), Ano6 mRNA was readily detectable in the patient's blood cells. RT-PCR analysis indicated expression of the default transcript as well as 2 alternatively spliced transcripts 1 and 2 (Supplemental Fig. 1). Due to the nature of the 2 mutations in the patient's cells (a splicing mutation in intron 6 and a frameshift mutation in exon 11), it is unlikely that these alternative transcripts are translated into a functional Ano6 protein, except for some residual correctly spliced precursor mRNA transcribed from the IVS6 $+1 \mathrm{G} \rightarrow$ A allele.

\section{Reduced aggregation-independent light-transmission changes and integrin inactivation of Scott platelets}

In platelets from control subjects, stimulation with convulxin/thrombin (stimulating GPVI and thrombin receptors) or ionomycin $\left(\mathrm{Ca}^{2+}\right.$ ionophore, conditions as in Fig. 2A) resulted in $51 \pm 3$ and $85 \pm 11 \%$ of PSexposing platelets, respectively (means $\pm \mathrm{SE}, n=8$ ). These values were not influenced by the integrin $\alpha_{\mathrm{IIb}} \beta_{3}$ inhibitor, tirofiban $(P>0.30)$. In Scott platelets, the same agonists evoked severely reduced but residual PS exposure of $1.7 \pm 0.5$ and $2.0 \pm 0.6 \%$ platelets $(n=3)$. Light transmission recording with control platelets indicated that convulxin/thrombin and ionomycin provoked rapid clearance of the cell suspensions; this effect was only partly reduced by tirofiban, inhibiting platelet aggregation (Fig. 2A, left panels). In line with earlier data (18), it is suggested that the residual increase in light transmission is due to shape change from discoid platelets to translucent, ballooned structures. Such ballooned platelets could indeed be observed by microscopy (Supplemental Fig. 2). In contrast, Scott platelets showed only limited changes in light transmission after stimulation in the presence of tirofiban (Fig. 2A, right panels). 

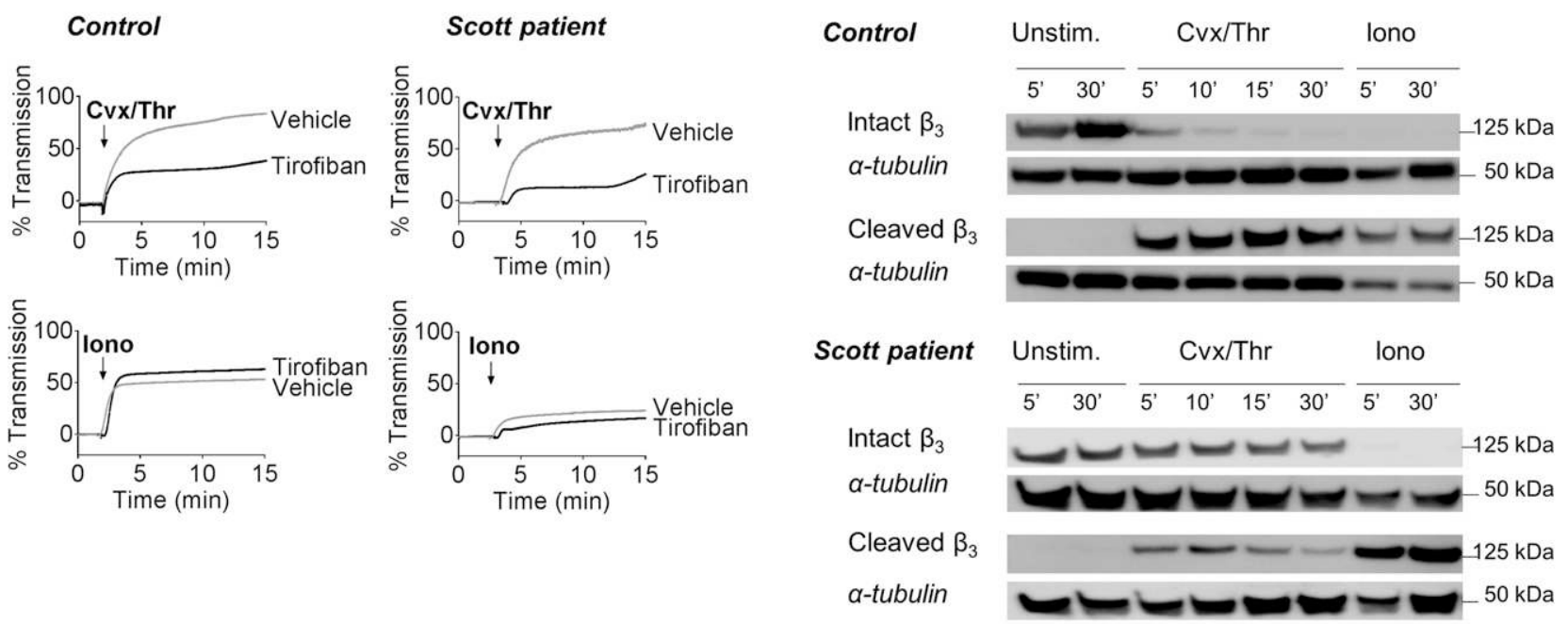

B
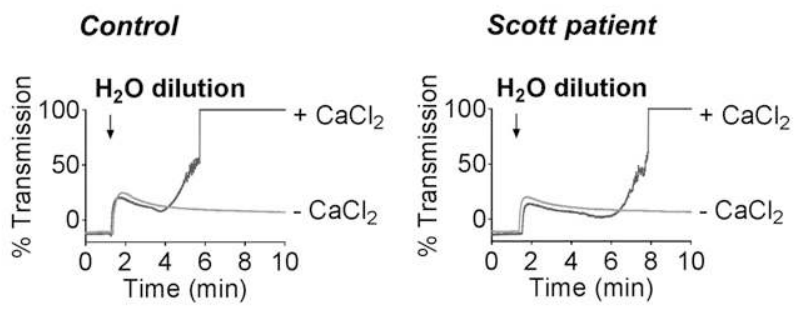

D

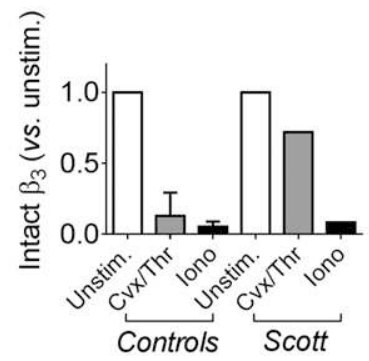

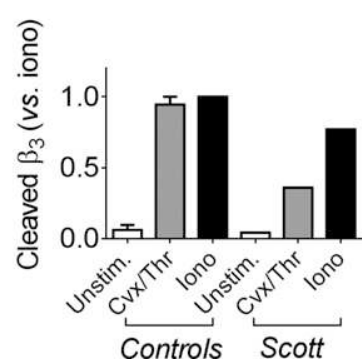

Figure 2. Integrin $\alpha_{I I b} \beta_{3}$-independent turbidity changes and reduced integrin cleavage by Scott syndrome platelets. $A$ ) Suspensions of washed platelets from control subjects or patients with Scott syndrome in $\mathrm{CaCl}_{2}$-containing medium were stimulated with convulxin $(\mathrm{Cvx}, 100 \mathrm{ng} / \mathrm{ml})$ plus thrombin (Thr, $4 \mathrm{nM}$ ) or with ionomycin (Iono, $10 \mu \mathrm{M}$ ) in the presence or absence of tirofiban $(2 \mu \mathrm{g} / \mathrm{ml})$. Shown are representative changes in light transmission $(n=3)$. B) Hypotonic shock response of PRP induced by dilution (33\%) in the presence or absence of $\mathrm{CaCl}_{2}(4 \mathrm{mM})$. Shown are representative traces of changes in light transmission. $C$ ) Western blots probed for the intact and cleaved $\beta_{3}$ chain (detected with Ab762 and Ab754, respectively) of platelets stimulated with $\mathrm{Cvx} / \mathrm{Thr}$ or Iono in the presence of $\mathrm{CaCl}_{2}$. Blots (representative for 3 performed) were reprobed with anti- $\alpha$-tubulin $\mathrm{mAb}$ as lane loading control. $D$ ) Quantification of $\beta_{3}$ chain cleavage ( $5 \mathrm{~min}$ ) from densitometric profiles. Means \pm SE $(n=4$ controls $)$.

In this case, no ballooned structures were seen (Supplemental Fig. 2).

Light transmission changes due to platelet swelling can also be assessed in the hypotonic shock response, which measures the reaction of platelets in plasma to dilution with water (34). Water-induced light transmission changes were comparable for control and Scott platelets, even in the presence of $\mathrm{CaCl}_{2}$ to stimulate $\mathrm{Ca}^{2+}$-dependent ion fluxes (Fig. $2 B$ ). With $\mathrm{CaCl}_{2}$ present, the late increase in light transmission accompanying balloon formation, however, was markedly delayed with Scott platelets. To determine a role of ion influxes, platelets were stimulated with ionomycin in hypertonic medium. Hypertonia resulted in delayed PS exposure and residual ballooning in control platelets, but failed to induce PS exposure or ballooning in Scott platelets (Supplemental Fig. 2).

In control cells, $\mathrm{Ca}^{2+}$-induced PS exposure is accompanied by calpain-mediated cleavage of the integrin $\beta_{3}$-chain, which results in inactivation of $\alpha_{\mathrm{II}} \beta_{3}$ (18). Similarly, in Scott platelets stimulation with ionomycin resulted in rapid $\beta_{3}$-chain cleavage, which was complete within 5 min (Fig. $2 C, D)$. However, stimulation with convulxin/thrombin led to a markedly delayed cleavage in the patient's platelets in comparison with control platelets. Together, these data point to a major defect in $\mathrm{Ca}^{2+}$ - and tonic-dependent light transmission clearance (balloon formation) and a partial defect in integrin $\beta_{3}$-chain cleavage in $\mathrm{Ca}^{2+}$-activated Scott platelets.

\section{Subtle role of murine Gardos channels in platelet PS exposure and thrombus formation}

Pharmacological studies with human platelets suggest a role for Gardos $\left(\mathrm{K}_{\mathrm{Ca}} 3.1\right) \mathrm{K}^{+}$channels in agonist-induced PS exposure (22). We reinvestigated a role of these channels in $\mathrm{Kcnn}^{-1}$ mice lacking the $\mathrm{K}_{\mathrm{Ca}} 3.1$ protein. Western blot analysis indicated weak expression of the $47-\mathrm{kDa}$ channel protein in platelets (platelets from Fig. $\mathbf{3 A}$ ) and erythrocytes (not shown) of wild-type, but not of $\mathrm{Kcnn}^{-/-}$, mice. After stimulation with convulxin/thrombin or ionomycin, $K c n n 4^{+/+}$and $K c n n 4^{-/-}$platelets were equally high in PS exposure (Fig. $3 B$ ). Whole-blood perfusion over collagen resulted in subtle changes in thrombus formation (Fig. 3C). 
Figure 3. Unchanged thrombus formation and PS exposure of mice lacking $\mathrm{K}_{\mathrm{Ca}} 3.1$ Gardos channels. A) Expression of $\mathrm{K}_{\mathrm{Ca}} 3.1$ protein in platelets from corresponding $\mathrm{Kcnn}^{+/+}$and $\mathrm{Kcnn} 4^{-/-}$mice; control lane refers to murine fibroblasts. Western blots are from cell lysates probed with anti-murine KCa3.1 $\mathrm{mAb}$, and reprobed with anti- $\beta$-actin $\mathrm{mAb}$ as loading control. B) Washed platelets from Kcnn $4^{+++}$or $\mathrm{Kcnn4^{-/- }}$ mice in $\mathrm{CaCl}_{2}$-containing medium were stimulated with convulxin $(\mathrm{Cvx}, 100 \mathrm{ng} / \mathrm{ml})$ plus thrombin (Thr, $4 \mathrm{nM}$ ), or with ionomycin (Iono, $10 \mu \mathrm{M}$ ), as indicated. Flow cytometric measurement of platelets binding A647-annexin A5, determined after $15 \mathrm{~min}$. $C$ and $D$ ) Blood from $\mathrm{Kcnn}^{+/+}$and $\mathrm{Kcnn} 4^{-/-}$mice was perfused over collagen for $4 \mathrm{~min}$ at $1000 \mathrm{~s}^{-1}$. Thrombi were stained with PE-JON/A mAb (integrin activation) FITC- $\alpha$ CD62P mAb (Pselectin expression) and AF647-annexin A5 (PS exposure). C) Representative phase-contrast and fluorescence images (scale bars, $25 \mu \mathrm{m}$ ). D) Quantitative analysis of surface area coverage (\%SAC) of thrombi or fluorescence. Dotted line indicates background fluorescence for PS exposure (no platelet thrombi). Means $\pm \mathrm{SE}$ $(n=5-7) . * P<0.05$ (2-way ANOVA)

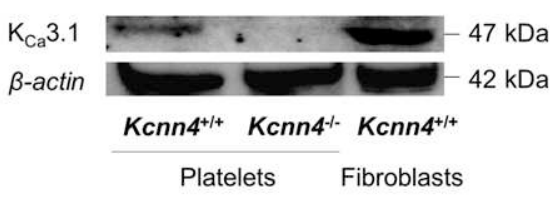

B

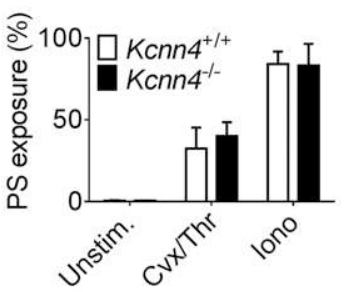

C
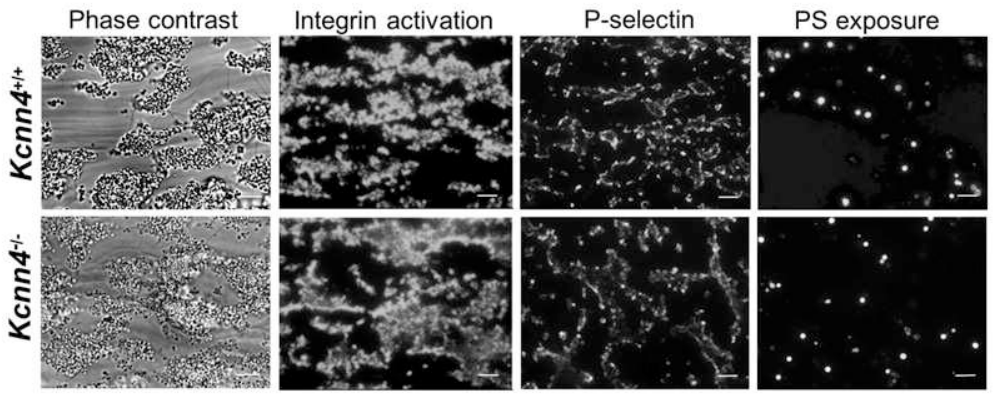

D
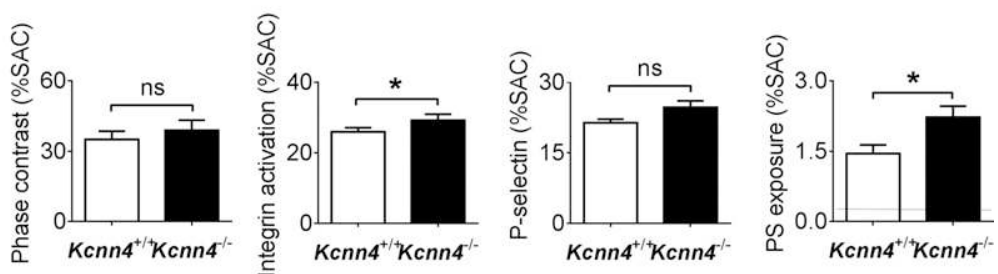

Whereas the overall deposition of Kcnn4-deficient platelets was unchanged $(P>0.1)$, these platelets were slightly but significantly more increased in $\alpha_{\mathrm{IIb}} \beta_{3}$ activation and PS exposure (Fig. 3D). Jointly, these data point to a minor negative rather than a positive role for the murine $\mathrm{K}_{\mathrm{Ca}} 3.1$ channel in collagen-dependent PS exposure.

\section{No role for murine Ano1 in platelet PS exposure or thrombus formation}

The isoform Ano1 is a ubiquitously expressed ion channel displaying $\mathrm{Ca}^{2+}$-dependent $\mathrm{Cl}^{-}$conductance and has been implicated in hemolysis-induced PS exposure of erythrocytes $(24,40)$. Evaluation of platelets from mice with genetic deficiency in Ano1 showed normal expression of the main surface glycoproteins (Supplemental Table 1) and normal activation in comparison to wild-type platelets with respect to agonist-induced integrin $\alpha_{\mathrm{II}} \beta_{3}$ activation, P-selectin expression, and PS exposure (Supplemental Table 2). Measurements of whole-blood thrombus formation on collagen demonstrated that platelet deposition, P-selectin expression, and PS exposure were similar for Ano1-deficient and corresponding wild-type mice (Supplemental Fig. 3, $P>0.1$ ).

\section{Lethality of Ano6-deficient mice and identification of Ano6 splice variants}

Several approaches were followed to obtain mice with genetic deficiency of Ano6. In 2 laboratories, we generated heterozygous $A n o \sigma^{+/-}$mice using the stem cell clone AW382 , carrying a $\beta$-geo reporter gene trap in the Ano6 gene
( $A n o 6^{A W}$ strain). These mice produced alive offspring with the gene trap insertion (data not shown), although at a lower number than expected. We hence investigated the embryos in heterozygous females at embryonic d 10.5, 12.5, and 16.5 of gestation. Morphologic examination indicated that at all time points, most embryos developed normally. However, several embryos were detected as death bodies, with exencephaly, or with signs of abdominal or intracranial bleeding (Fig. 4A, B). Western blot analysis indicated that platelets from surviving $A n o 6^{A W_{+} /-}$mice with gene trap insertion had significant expression of Ano6 protein (Fig. 4C), and hence were not homozygously deficient in this gene.

In addition, we used heterozygous Ano6-deficient mice from the $A n o \sigma^{\text {Avor }}$ strain, described before (29). Inbreeding resulted in offspring with $\sim 30 \%$ of the expected number of $A$ no $6^{A \text { tior- } /-}$ sucklings. In contrast to the $A n o \sigma^{A W}$ strain, no lethality or obvious bleeding was seen in fetuses at embryonic d 14.5-18.5. As described previously (29), several deficient fetuses died around birth (e.g., due to asphyxia). However, $\sim 30 \%$ of $A$ no $\sigma^{-1}$ mice survived longer than 2 mo (Ano6 $6^{\text {Avor }}$ strain), and these were used for phenotypic analysis. RT-PCR analyses of tissues from the surviving Ano $6^{\text {Avor-/- }}$ mice (C57BL/6 background) showed residual Ano6 mRNA expression, which was explained by the presence of alternative transcript 1 (Supplemental Fig. 4). Western blot analysis indicated that in platelets from Ano6 Avor $-1-^{-}$mice the $106 \mathrm{kDa}$ Ano6 protein was absent (Fig. $4 D$ ), thus indicating that the alternative transcript was not efficiently transcribed. Markedly, tail bleed time was prolonged in adult $A n o 6^{\text {Avor }-/-}$ mice (28.6 $\left.\pm 7.5 \mathrm{~min}\right)$ in comparison with Ano ${ }^{\text {Avort/- }}(4.9 \pm 1.8 \mathrm{~min})$ and $A$ no $6^{\text {Avort++ }}$ $(6.4 \pm 1.6 \mathrm{~min})$ animals (means $\pm \mathrm{sE}, n=5-7, P<0.05)$. 


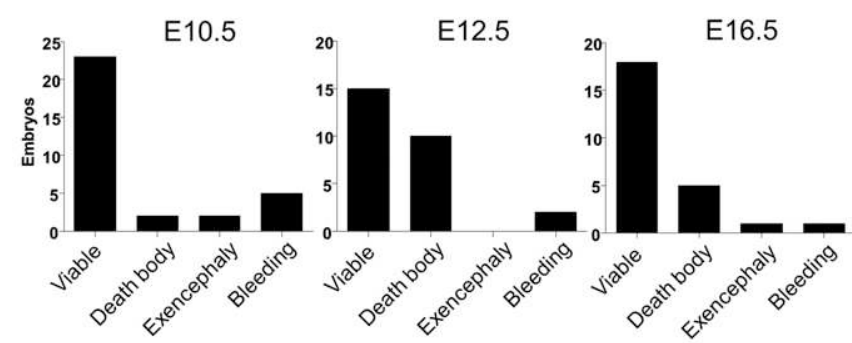

B Ano6 ${ }^{A W}$
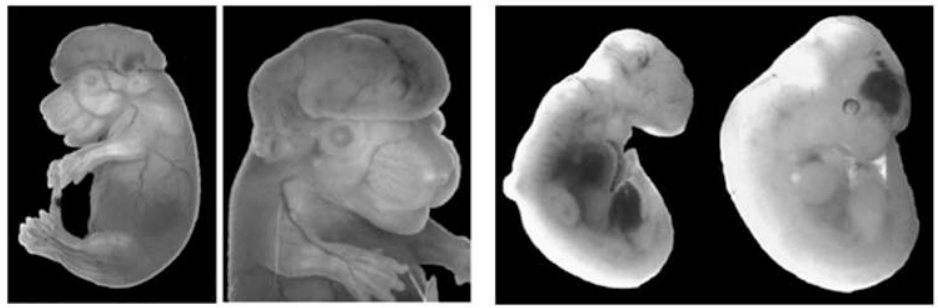

D Ano6 ${ }^{\text {Avor }}$

C Ano6 $^{A W}$
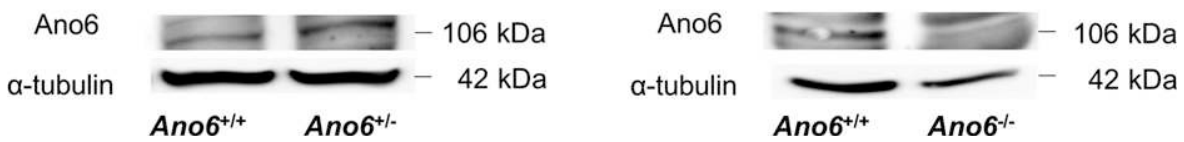

Figure 4. Embryonic lethality after breeding of Ano6-deficient mice. A) Viability of embryos generated by inbreeding of heterozygous $A n o \sigma^{+/-}$ mice $\left(A n o \sigma^{A W}\right.$ strain) at gestational d (E) 10.5, 12.5, or 16.5. B) Embryo presenting with exencephaly (left, embryonic d 16.5), embryos presenting with major abdominal and intracranial bleeding (embryonic d 12.5). $C$ and $D$ ) Westerns blots of Ano6 protein expression in platelet lysates from heterozygous $A n o \sigma^{+/-}$mice (Ano6 ${ }^{A W}$ strain) $(C)$ and homozygous Ano $\sigma^{/-}$mice $\left(A n o 6^{\text {Avor }}\right.$ strain) $(D)$.
Residual PS exposure and abolished swelling of Ano6deficient mouse platelets in thrombus formation

We then compared activation characteristics of platelets from mice of the $A n o \sigma^{A W}$ and $A n o \sigma^{A v o r}$ strains. Platelets from both types of heterozygous mice expressed normal levels of surface glycoproteins (Supplemental Table 1) and were unchanged in $\alpha_{\mathrm{IIb}} \beta_{3}$ activation, P-selectin expression and PS exposure, when compared with corresponding wild-type platelets (Supplemental Table 2). Flow perfusion experiments, performed with $A n o 6^{A W+/-}$ or $A n o 6^{\text {Avor+/- }}$ blood did not reveal significant changes in parameters of thrombus formation, including PS exposure, in comparison with the wild-type blood (Supplemental Figs. 5 and 6). On the other hand, isolated erythrocytes from heterozygous $A n o \sigma^{A W+/-}$ or $A n o \sigma^{A v o r+/-}$ mice displayed a significant lower ionomycin-induced PS exposure by $34.0 \pm 6.6$ or $31.6 \pm 8.1 \%$, respectively, compared with corresponding wild-type erythrocytes (means $\pm \mathrm{SE}, n=4-5, P<0.05$ ).

We then assessed thrombus formation on collagen using blood from surviving adult homozygous deficient $A$ no $\sigma^{\prime-}$ mice (Ano6 ${ }^{\text {Avor }}$ strain). Thrombus formation as such was unchanged, with similar platelet adhesion, integrin $\alpha_{\mathrm{IIb}} \beta_{3}$ activation and P-selectin expression, in comparison with thrombi from wild-type mice (Fig. $5 A, B)$. However, although wild-type thrombi showed $1-2 \%$ of the surface as PS exposure, as before (18), the $A$ no $6^{\text {Avor- } /-}$ thrombi displayed a substantial $76.2 \pm 2.6 \%(n=4, P<0.05)$ reduction of this parameter (Fig. $5 B$ ). High-magnification images indicated residual patches of PS exposure in some of the collagen-bound Ano6 ${ }^{\text {Avor- }-}$ platelets (Fig. 5A, insert). Notably, these platelets with residual PS exposure were smaller than the $8 \mu \mathrm{m}$ ballooning structures seen with wild-type platelets. Image quantification further learned that platelet ballooning was essentially abolished in Ano6 ${ }^{\text {Avor- }-/-}$ blood samples (Fig. $5 B$ ).

Activation studies indicated that ADP-, thrombin-, and convulxin-induced integrin activation and P-selectin expression were unaffected in washed $A$ no $6^{\text {Avor- } /-}$ platelets (Supplemental Table 2). On the other hand, in these knockout platelets PS exposure in response to ionomycin (data not shown) or convulxin/thrombin (Fig. 6A, B) was strongly impaired. In $\sim 10 \%$ of the platelets residual, low PS exposure was observed after stimulation with convulxin/ thrombin.

Human Scott platelets display a partly reduced PS exposure in response to the apoptosis-stimulating agent ABT-737 (11). In particular, flow cytometric analysis of ABT-737-treated patient's platelets indicated a reduced fraction with high PS exposure (M3 fraction), and an increased fraction with moderate PS exposure (M2 fraction), which can form at minimal or low $\mathrm{Ca}^{2+}$ rises. We studied this ABT-737-induced response in Ano $6^{\text {Avor- } /-}$ platelets and noted that, similarly, the M2 fraction (moderate PS exposure) was increased at the expense of the M3 fraction (high PS exposure), when compared with wild-type control platelets (Fig. 6C,D).

\section{Impaired aggregation-independent light transmission changes and integrin inactivation of Ano6-deficient mouse platelets}

Similarly to human platelets, wild-type mouse platelets stimulated with convulxin/thrombin or ionomycin showed light transmission changes in the presence of 
Figure 5. Normal thrombus formation, residual PS exposure, and abolished ballooning in the absence of Ano6. Blood from corresponding $A n o \sigma^{+/+}$ and $A$ no $\sigma^{-/-}$mice $\left(A n o 6^{A v o r}\right.$ strain) was perfused over collagen for $4 \mathrm{~min}$ at $1000 \mathrm{~s}^{-1}$. Thrombi on the surface were stained as indicated for Fig. 3. A) Representative phase-contrast and fluorescence images (scale bars, $25 \mu \mathrm{m}$; insets, $25 \times 25 \mu \mathrm{m})$. $B$ ) Surface area coverage (\%SAC) of thrombi or fluorescence from integrin activation, P-selectin expression, PS exposure, and ballooning. Dotted line indicates background fluorescence for PS exposure (no platelet thrombi). Means $\pm \operatorname{SE}(n=3) . * P<0.05$ (2-way ANOVA).
A

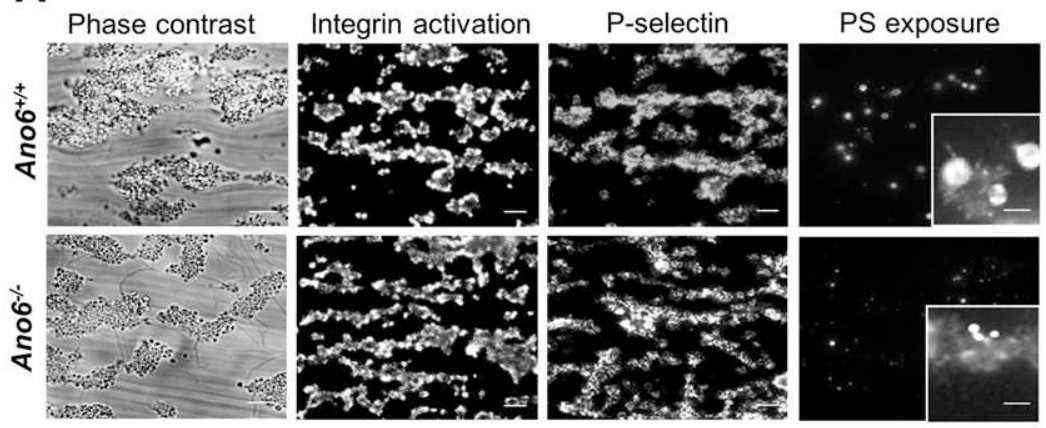

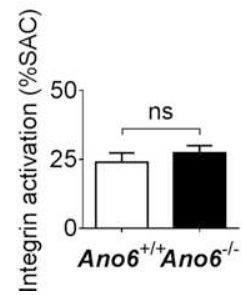

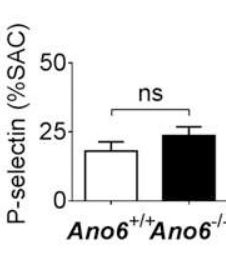

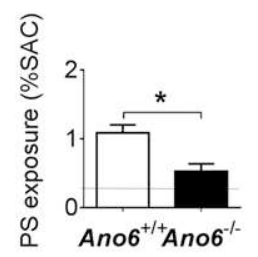

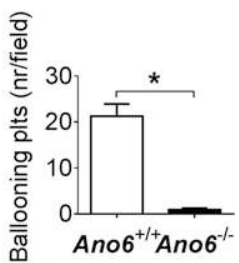

tirofiban to block platelet aggregation due to clearance of the platelet suspension (Fig. 7A). This clearance was substantially lower $(-80 \%)$ for Ano6-deficient platelets. In PRP, we monitored the dilution-induced hypotonic shock response, which was similar for Ano6-deficient and wildtype platelets (Fig. $7 \mathrm{~B}$ ). Yet, with $\mathrm{CaCl}_{2}$ present, the later increase in light transmission accompanying balloon formation was greatly delayed in the deficient platelets. Finally, we determined the cleavage of the integrin $\beta_{3}$-chain in response to convulxin/thrombin, which remained partial for $30 \mathrm{~min}$ in $A n o \sigma^{\text {Avor- } /-}$ platelets (reduction to $-60 \%)$, whereas it was complete in this time frame in Ano $6^{\text {Avor }+/+}$ platelets (Fig. $7 C, D$ ). Ionomycin-induced $\beta_{3^{-}}$ chain cleavage was not different in the presence or absence of Ano6. In control experiments, we established that the $\beta_{3}$-chain cleavage was annulled by the calpain inhibitor calpeptin, as described before (18), indicating it was due to calpain-dependent proteolytic activity. Together, these findings demonstrate a major deficiency in $\mathrm{Ca}^{2+}$-dependent light transmission clearance (balloon formation) and a partial defect in integrin $\beta_{3}$-chain cleavage in platelets from the Ano6-deficient mice.

\section{DISCUSSION}

In the present work, we compared the activation properties of human Scott platelets with those of mouse platelets lacking one of the transmembrane proteins previously linked to PS exposure, the $\mathrm{K}_{\mathrm{Ca}} 3.1$ Gardos channels or the Ano1 or Ano6. Although pharmacological evidence (using clotrimazol and charybdotoxin) has suggested a positive
Figure 6. Residual $\mathrm{Ca}^{2+}$-dependent PS exposure by Ano6-deficient platelets. $A$ and $B$ ) Washed platelets from corresponding $A n o \sigma^{+/+}$ and $A$ no $\sigma^{-/-}$mice $\left(A n o \sigma^{A v o r}\right.$ strain) were stimulated in $\mathrm{CaCl}_{2}$ containing medium with convulxin $(\mathrm{Cvx} 100 \mathrm{ng} / \mathrm{ml})$ plus thrombin (Thr, $4 \mathrm{nM}$ ) for $30 \mathrm{~min}$. $C$ and $D$ ) Washed platelets were stimulated with the $\mathrm{BH} 3$ mimetic ABT-737 $(10 \mu \mathrm{M})$ for $1 \mathrm{~h}$. Shown are representative histograms of AF647-annexin A5 binding after stimulation (black lines) or vehicle controls (gray lines). Markers M1, M2, and M3 indicate fractions of platelets with no, moderate, or high annexin A5 binding, respectively. Means \pm SE $(n=3-4)$. $* P<0.05$ vs. wild-type (2-way ANOVA).
A
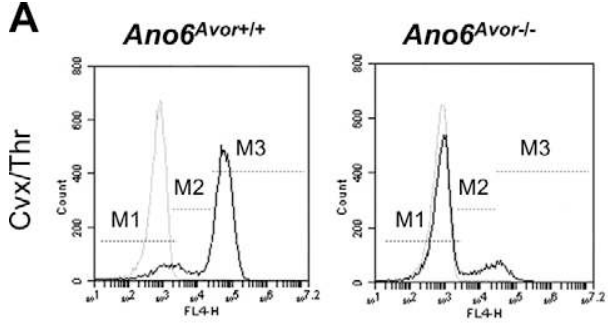

B

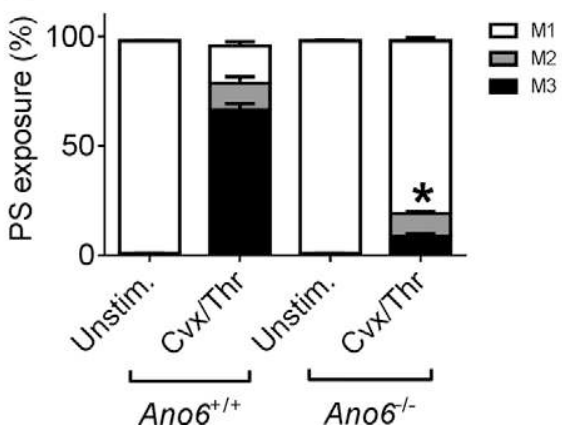

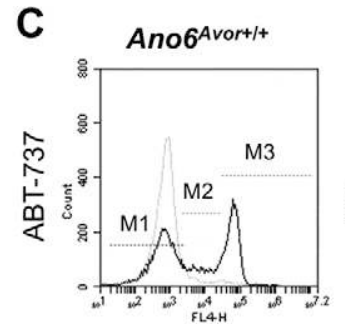
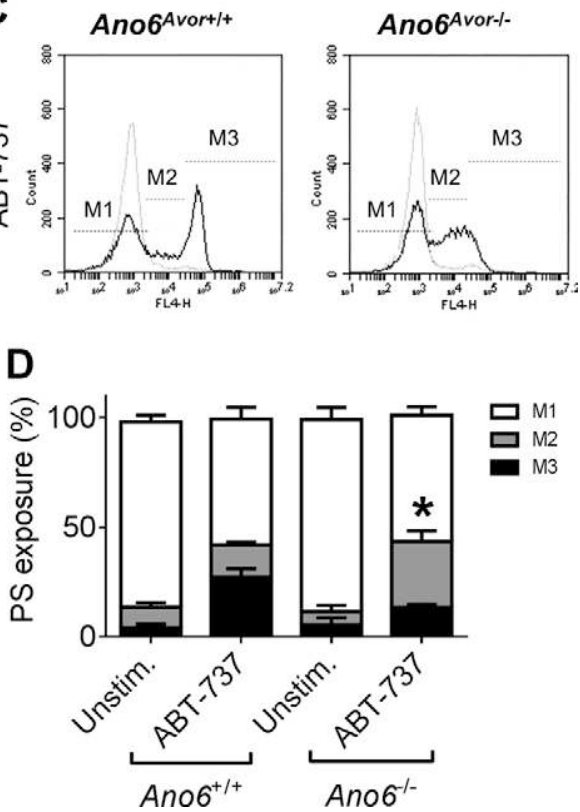

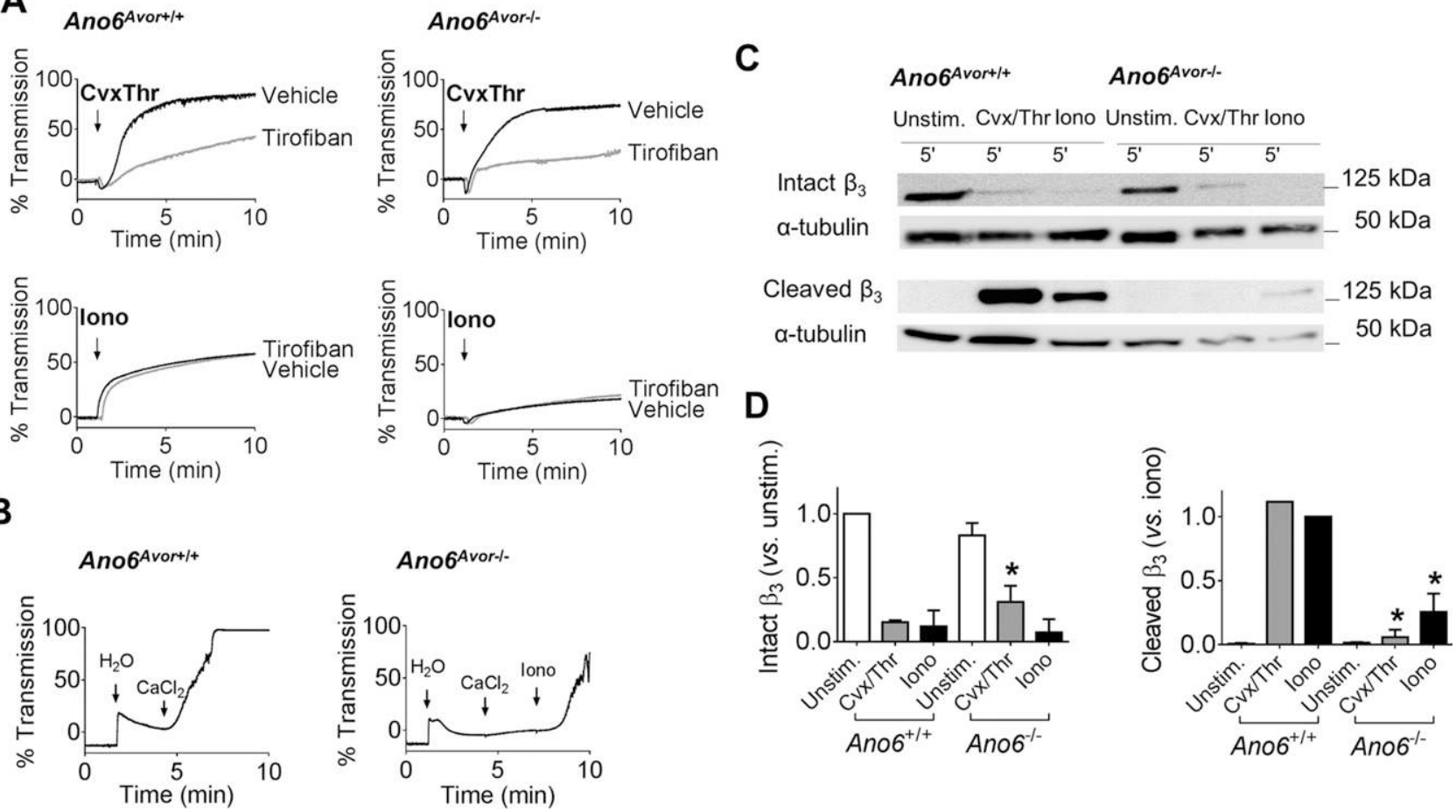

Figure 7. Integrin $\alpha_{\mathrm{IIb}} \beta_{3}$-independent turbidity changes and reduced integrin cleavage by Ano6-deficient platelets. $A$ ) Suspensions of washed platelets from corresponding $A n o \sigma^{+/+}$and $A n o \sigma^{/-}$mice (Ano $\sigma^{\text {Avor }}$ strain) in $\mathrm{CaCl}_{2}$-containing medium were stimulated with convulxin $(\mathrm{Cvx}, 100 \mathrm{ng} / \mathrm{ml})$ plus thrombin $(\mathrm{Thr}, 4 \mathrm{nM})$ or with ionomycin (Iono, $10 \mu \mathrm{M})$ in the presence or absence of tirofiban $(2 \mu \mathrm{g} / \mathrm{ml})$. Shown are representative changes in light transmission $(n=3)$. B) Hypotonic shock response of PRP by water dilution (33\%) in the presence or absence of $\mathrm{CaCl}_{2}(4 \mathrm{mM})$. Shown are representative traces of changes in light transmission. C) Western blots probed for the intact and cleaved integrin $\beta_{3}$ chain (detected with Ab762 and Ab754, respectively)

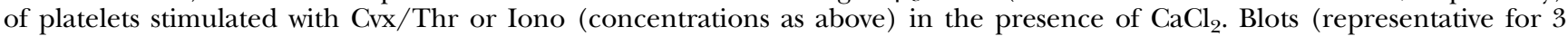
performed) were reprobed with anti- $\alpha$-tubulin mAb as lane loading control. $D$ ) Quantification of $\beta_{3}$ chain cleavage from densitometric profiles. Means $\pm \mathrm{SE}(n=3)$. ${ }^{*} P<0.05$.

role of the $\mathrm{K}_{\mathrm{Ca}} 3.1$ channels in PS exposure in human platelets (22), we could not confirm this in $\mathrm{Kcnn}^{-1-}$ mice. Instead, upon thrombus formation on collagen, $\mathrm{K}_{\mathrm{Ca}} 3.1$ deficiency increased PS exposure along with integrin activation, suggesting that this channel suppresses rather than stimulates platelet activation. Assuming that the $\mathrm{K}_{\mathrm{Ca}} 3.1$ channels act similarly in human and mouse platelets, the difference with previously published data $(21,22)$ might be explained by off-target effects of the pharmacological inhibitors used.

Anol can function as a $\mathrm{Ca}^{2+}$-activated $\mathrm{Cl}^{-}$channel (16, 23) and has been implicated in PS exposure in erythrocytes treated with $\alpha$-hemolysin (24). In smooth muscle cells, Anol can regulate cell proliferation (40). In the present experiments, we could not confirm a role of Anol in $\mathrm{Ca}^{2+}$ dependent PS exposure, given that $\mathrm{AnoI}^{-/-}$mouse platelets responded normally to collagen, convulxin/thrombin, or ionomycin.

Earlier studies indicated that murine deficiency in Ano6 affects mineral deposition in skeletal tissue (29) and arterial thrombus formation in vivo (17). By cross-breeding we could obtain viable and adult $A$ no $\sigma^{\prime-}$ offspring from mice of the $A n o \sigma^{A v o r}$ but not of the $A n o \sigma^{A W}$ strain. Although this remains to be confirmed, the survival of the Ano $6^{\text {Avor- } /-}$ mice might be related to the expression of alternative Ano6 mRNA transcripts in key tissues. On the other hand, heterozygous $A n o G^{A W_{+} /-}$and $A n o 6^{\text {Avor+/- }}$ mice survived normally without obvious phenotypic defects. In the heterozygous mice, thrombus formation and platelet activation properties were unchanged in our hands, but heterozygous erythrocytes from both lines showed a reduced ionomycin-induced PS exposure.

Using blood from the surviving Ano $6^{\text {Avor- /- }}$ mice, we found that collagen-dependent thrombus formation was unchanged in terms of platelet deposition, aggregation, integrin activation, and secretion. On the other hand, collagen-dependent PS exposure in platelets was greatly but not completely reduced, and morphologic changes to a ballooning structure were abolished. A similar, combined defect in platelet PS exposure and ballooning was observed with blood from the patients with Scott syndrome.

Phenotypic resemblance of the $A n o \sigma^{\text {Avor }-/-}$ and patient platelets was also noticed from flow cytometric studies. In both $A n o \sigma^{-1}$ and Scott platelets, PS exposure was mostly, yet incompletely, reduced after convulxin/thrombin treatment and was slightly diminished upon apoptosis stimulation with ABT-737. Furthermore, the platelets from Ano6-deficient mice and the patients with Scott syndrome displayed a reduction in convulxin/thrombin-induced integrin $\beta_{3}$ cleavage, likely due to reduced calpain activation (18). Together, these data indicate that the functional and morphologic alterations found in platelets from the patients with Scott syndrome are quite well phenocopied in platelets from Ano6-deficient mice. 
As summarized elsewhere $(17,23,41,42)$, Ano6 can function not only as a $\mathrm{Ca}^{2+}$-dependent phospholipid scramblase but also as a chloride and cation channel. The inability of Ano6-deficient platelets to form balloons-like Scott platelets-suggests a defect in $\mathrm{Ca}^{2+}$-dependent ion influx and swelling. This idea is confirmed by our finding that a hypertonic environment markedly delays the PS exposure and balloon formation. The swelling seems to be a consequence of multiple ion influxes, as we found that specific depletion of $\mathrm{Cl}^{-}$or $\mathrm{Na}^{+}$ions was without effect (unpublished results). On the other hand, it should be noted that also other $\mathrm{Ca}^{2+}$ channels, in particular Orail and TRPC isoforms, can contribute to PS exposure in platelets $(43,44)$.

Scott syndrome has been described as a moderate bleeding disorder, with hemorrhagic episodes only after trauma or childbirth $(2,3)$. Although the syndrome is rare (with 3 patients characterized so far), it is likely underdiagnosed. The present data with Ano6 $6^{\text {Avor- } /-}$ mice, despite a reduced survival, point to limited hemostatic insufficiency, as mouse tail bleed times were increased. The residual platelet PS exposure and delayed thrombin and fibrin generation in addition may explain the limited severity of bleeding. Interestingly, we have identified in both mouse and human samples alternative splice variants of Ano6. In agreement with this finding, also other authors describe the expression of Ano6 splice variants, which differ in their N-terminal cytoplasmic domains, but are similar in PS scrambling activities, in different human tissues (45). In humans, the nature of the 2 ANO6 gene mutations in the patients with Scott syndrome leads to impaired translation of all identified splice variants. In mice, the tissue distribution of the splice variants is still unclear. These variants might be of functional importance during embryonic development and at later life. On the other hand, we could not detect Ano6 protein expression and hence found no evidence for a role of these splice variants, in the residual PS exposure in human Scott syndrome or mouse Ano $6^{\text {Avor- } /-}$ platelets. Not unlikely, other $\mathrm{Ca}^{2+}$-dependent Ano isoforms (23), enforced by Orail and TRPC $\mathrm{Ca}^{2+}$ entry channels $(43,44)$, may account for the low PS exposure in the absence of Ano6 channels.

This work was supported by grants from the Cardiovascular Center Maastricht, and the Dutch Heart Foundation 2011T6 (to N.J.A.M., J.M.E.M.C., and J.W.M.H.), and Deutsche Forschungsgemeinschaft DFG SFB699, project A7\&A12 (to R.S. and K.K.). The authors declare no conflicts of interest.

\section{REFERENCES}

1. Sims, P. J., Wiedmer, T., Esmon, C. T., Weiss, H. J., and Shattil, S. J. (1989) Assembly of the platelet prothrombinase complex is linked to vesiculation of the platelet plasma membrane. Studies in Scott syndrome: an isolated defect in platelet procoagulant activity. J. Biol. Chem. 264, 17049-17057

2. Toti, F., Satta, N., Fressinaud, E., Meyer, D., and Freyssinet, J. M. (1996) Scott syndrome, characterized by impaired transmembrane migration of procoagulant phosphatidylserine and hemorrhagic complications, is an inherited disorder. Blood 87, 1409-1415

3. Satta, N., Toti, F., Fressinaud, E., Meyer, D., and Freyssinet, J. M. (1997) Scott syndrome: an inherited defect of the procoagulant activity of platelets. Platelets 8, 117-124
4. Munnix, I. C., Harmsma, M., Giddings, J. C., Collins, P. W., Feijge, M. A., Comfurius, P., Heemskerk, J. W., and Bevers, E. M. (2003) Store-mediated calcium entry in the regulation of phosphatidylserine exposure in blood cells from Scott patients. Thromb. Haemost. 89 687-695

5. Bevers, E. M., Comfurius, P., and Zwaal, R. F. (1983) Changes in membrane phospholipid distribution during platelet activation. Biochim. Biophys. Acta 736, 57-66

6. Zwaal, R. F. A., and Schroit, A. J. (1997) Pathophysiologic implications of membrane phospholipid asymmetry in blood cells. Blood 89, 1121-1132

7. Williamson, P., Christie, A., Kohlin, T., Schlegel, R. A., Comfurius, P., Harmsma, M., Zwaal, R. F. A., and Bevers, E. M. (2001) Phospholipid scramblase activation pathways in lymphocytes. Biochemistry 40, 8065-8072

8. Heemskerk, J. W., Mattheij, N. J., and Cosemans, J. M. (2013) Platelet-based coagulation: different populations, different functions. J. Thromb. Haemost. 11, 2-16

9. Schoenwaelder, S. M., Yuan, Y., Josefsson, E. C., White, M. J., Yao, Y., Mason, K. D., O'Reilly, L. A., Henley, K. J., Ono, A., Hsiao, S., Willcox, A., Roberts, A. W., Huang, D. C., Salem, H. H., Kile, B. T., and Jackson, S. P. (2009) Two distinct pathways regulate platelet phosphatidylserine exposure and procoagulant function. Blood 114, 663-666

10. Kmit, A., van Kruchten, R., Ousingsawat, J., Mattheij, N. J., Senden-Gijsbers, B., Heemskerk, J. W., Schreiber, R., Bevers, E. M., and Kunzelmann, K. (2013) Calcium-activated and apoptotic phospholipid scrambling induced by Ano6 can occur independently of Ano6 ion currents. Cell Death Dis. 4, e611

11. Van Kruchten, R., Mattheij, N. J., Saunders, C., Feijge, M. A., Swieringa, F., Wolfs, J. L., Collins, P. W., Heemskerk, J. W., and Bevers, E. M. (2013) Both TMEM16F-dependent and TMEM16Findependent pathways contribute to phosphatidylserine exposure in platelet apoptosis and platelet activation. Blood 121, 1850-1857

12. Suzuki, J., Umeda, M., Sims, P. J., and Nagata, S. (2010) Calciumdependent phospholipid scrambling by TMEM16F. Nature $\mathbf{4 6 8}$, 834-838

13. Castoldi, E., Collins, P. W., Williamson, P. L., and Bevers, E. M. (2011) Compound heterozygosity for 2 novel TMEM16F mutations in a patient with Scott syndrome. Blood 117, 4399-4400

14. Brunner, J. D., Lim, N. K., Schenck, S., Duerst, A., and Dutzler, R. (2014) X-ray structure of a calcium-activated TMEM16 lipid scramblase. Nature 516, 207-212

15. Martins, J. R., Faria, D., Kongsuphol, P., Reisch, B., Schreiber, R., and Kunzelmann, K. (2011) Anoctamin 6 is an essential component of the outwardly rectifying chloride channel. Proc. Natl. Acad. Sci. USA 108, 18168-18172

16. Tian, Y., Schreiber, R., and Kunzelmann, K. (2012) Anoctamins are a family of $\mathrm{Ca}^{2+}$-activated $\mathrm{Cl}^{-}$channels. J. Cell Sci. 125, 4991-4998

17. Yang, H., Kim, A., David, T., Palmer, D., Jin, T., Tien, J., Huang, F., Cheng, T., Coughlin, S. R., Jan, Y. N., and Jan, L. Y. (2012) TMEM16F forms a $\mathrm{Ca}^{2+}$-activated cation channel required for lipid scrambling in platelets during blood coagulation. Cell 151, 111-122

18. Mattheij, N. J., Gilio, K., van Kruchten, R., Jobe, S. M., Wieschhaus, A. J., Chishti, A. H., Collins, P., Heemskerk, J. W., and Cosemans, J. M. (2013) Dual mechanism of integrin $\alpha_{\mathrm{IIb}} \beta_{3}$ closure in procoagulant platelets. J. Biol. Chem. 288, 13325-13336

19. Clark, S. R., Thomas, C. P., Hammond, V. J., Aldrovandi, M., Wilkinson, G. W., Hart, K. W., Murphy, R. C., Collins, P. W., and O'Donnell, V. B. (2013) Characterization of platelet aminophospholipid externalization reveals fatty acids as molecular determinants that regulate coagulation. Proc. Natl. Acad. Sci. USA 110, $5875-5880$

20. Okada, Y., Shimizu, T., Maeno, E., Tanabe, S., Wang, X., and Takahashi, N. (2006) Volume-sensitive chloride channels involved in apoptotic volume decrease and cell death. J. Membr. Biol. 209, 21-29

21. Lang, P. A., Kaiser, S., Myssina, S., Wieder, T., Lang, F., and Huber, S. M. (2003) Role of $\mathrm{Ca}^{2+}$-activated $\mathrm{K}^{+}$channels in human erythrocyte apoptosis. Am. J. Physiol. Cell Physiol. 285, C1553-C1560

22. Wolfs, J. L., Wielders, S. J., Comfurius, P., Lindhout, T., Giddings, J. C., Zwaal, R. F., and Bevers, E. M. (2006) Reversible inhibition of the platelet procoagulant response through manipulation of the Gardos channel. Blood 108, 2223-2228

23. Suzuki, J., Fujii, T., Imao, T., Ishihara, K., Kuba, H., and Nagata, S. (2013) Calcium-dependent phospholipid scramblase activity of TMEM16 protein family members. J. Biol. Chem. 288, $13305-13316$ 
24. Skals, M., Jensen, U. B., Ousingsawat, J., Kunzelmann, K., Leipziger, J., and Praetorius, H. A. (2010) Escherichia coli $\alpha$-hemolysin triggers shrinkage of erythrocytes via $\mathrm{K}_{(\mathrm{Ca})} 3.1$ and TMEM16A channels with subsequent phosphatidylserine exposure. J. Biol. Chem. 285, 15557-15565

25. Siljander, P., Farndale, R. W., Feijge, M. A., Comfurius, P., Kos, S., Bevers, E. M., and Heemskerk, J. W. (2001) Platelet adhesion enhances the glycoprotein VI-dependent procoagulant response: Involvement of p38 MAP kinase and calpain. Arterioscler. Thromb. Vasc. Biol. 21, 618-627

26. Grgic, I., Kaistha, B. P., Paschen, S., Kaistha, A., Busch, C., Si, H., Köhler, K., Elsässer, H. P., Hoyer, J., and Köhler, R. (2009) Disruption of the Gardos channel $\left(\mathrm{K}_{\mathrm{Ca}} 3.1\right)$ in mice causes subtle erythrocyte macrocytosis and progressive splenomegaly. Pflugers Arch. 458, 291-302

27. Si, H., Heyken, W. T., Wölfle, S. E., Tysiac, M., Schubert, R., Grgic, I., Vilianovich, L., Giebing, G., Maier, T., Gross, V., Bader, M., de Wit, C., Hoyer, J., and Köhler, R. (2006) Impaired endothelium-derived hyperpolarizing factor-mediated dilations and increased blood pressure in mice deficient of the intermediate-conductance $\mathrm{Ca}^{2+}$ activated K+ channel. Circ. Res. 99, 537-544

28. Brähler, S., Kaistha, A., Schmidt, V.J., Wölfle, S. E., Busch, C., Kaistha, B. P., Kacik, M., Hasenau, A. L., Grgic, I., Si, H., Bond, C. T., Adelman, J. P., Wulff, H., de Wit, C., Hoyer, J., and Köhler, R. (2009) Genetic deficit of SK3 and IK1 channels disrupts the endothelium-derived hyperpolarizing factor vasodilator pathway and causes hypertension. Circulation 119, 2323-2332

29. Ehlen, H. W., Chinenkova, M., Moser, M., Munter, H. M., Krause, Y., Gross, S., Brachvogel, B., Wuelling, M., Kornak, U., and Vortkamp, A. (2013) Inactivation of anoctamin-6/Tmem16f, a regulator of phosphatidylserine scrambling in osteoblasts, leads to decreased mineral deposition in skeletal tissues. J. Bone Miner. Res. 28, 246-259

30. Van Kruchten, R., Cosemans, J. M., and Heemskerk, J. W. (2012) Measurement of whole blood thrombus formation using parallelplate flow chambers - a practical guide. Platelets 23, 229-242

31. Van der Meijden, P. E., Feijge, M. A., Swieringa, F., Gilio, K., Nergiz-Unal, R., Hamulyák, K., and Heemskerk, J. W. (2012) Key role of integrin $\alpha\left(_{\text {IIb) }} \beta\right.$ (3) signaling to Syk kinase in tissue factor-induced thrombin generation. Cell. Mol. Life Sci. 69, 3481-3492

32. Kuijpers, M. J., van der Meijden, P. E., Feijge, M. A., Mattheij, N. J., May, F., Govers-Riemslag, J., Meijers, J. C., Heemskerk, J. W., Renné, T., and Cosemans, J. M. (2014) Factor XII regulates the pathological process of thrombus formation on ruptured plaques. Arterioscler. Thromb. Vasc. Biol. 34, 1674-1680

33. Deppermann, C., Cherpokova, D., Nurden, P., Schulz,J. N., Thielmann, I., Kraft, P., Vögtle, T., Kleinschnitz, C., Dütting, S., Krohne, G., Eming, S. A., Nurden, A. T., Eckes, B., Stoll, G., Stegner, D., and Nieswandt, B. (2013) Gray platelet syndrome and defective thrombo-inflammation in Nbeal2-deficient mice. J. Clin. Invest. 123, 3331-3342

34. Holme, S., Moroff, G., and Murphy, S.; Biomedical Excellence for Safer Transfusion Working Party of the International Society of Blood Transfusion. (1998) A multi-laboratory evaluation of in vitro platelet assays: the tests for extent of shape change and response to hypotonic shock. Transfusion 38, 31-40

35. De Witt, S. M., Swieringa, F., Cavill, R., Lamers, M. M., van Kruchten, R., Mastenbroek, T., Baaten, C., Coort, S., Pugh, N., Schulz, A.,
Scharrer, I., Jurk, K., Zieger, B., Clemetson, K. J., Farndale, R. W., Heemskerk, J. W., and Cosemans, J. M. (2014) Identification of platelet function defects by multi-parameter assessment of thrombus formation. Nat. Commun. 5, 4257

36. Gilio, K., Munnix, I. C., Mangin, P., Cosemans, J. M., Feijge, M. A., van der Meijden, P. E., Olieslagers, S., Chrzanowska-Wodnicka, M. B., Lillian, R., Schoenwaelder, S., Koyasu, S., Sage, S. O., Jackson, S. P., and Heemskerk, J. W. (2009) Non-redundant roles of phosphoinositide 3 -kinase isoforms $\alpha$ and $\beta$ in glycoprotein VIinduced platelet signaling and thrombus formation. J. Biol. Chem. 284, 33750-33762

37. De Witt, S., Swieringa, F., Cosemans, J. M., and Heemkerk, J. W. (2014) Thrombus formation on microspotted arrays of thrombogeneic surfaces. Nat. Protocol Exchange 2014, 3309

38. Kuijpers, M.J., Schulte, V., Bergmeier, W., Lindhout, T., Brakebusch, C., Offermanns, S., Fässler, R., Heemskerk, J. W., and Nieswandt, B. (2003) Complementary roles of glycoprotein VI and $\alpha_{2} \beta_{1}$ integrin in collagen-induced thrombus formation in flowing whole blood ex vivo. FASEB J. 17, 685-687

39. Burkhart, J. M., Vaudel, M., Gambaryan, S., Radau, S., Walter, U., Martens, L., Geiger, J., Sickmann, A., and Zahedi, R. P. (2012) The first comprehensive and quantitative analysis of human platelet protein composition allows the comparative analysis of structural and functional pathways. Blood 120, e73-e82

40. Wang, M., Yang, H., Zheng, L. Y., Zhang, Z., Tang, Y. B., Wang, G. L., Du, Y. H., Lv, X. F., Liu, J., Zhou, J. G., and Guan, Y. Y. (2012) Downregulation of TMEM16A calcium-activated chloride channel contributes to cerebrovascular remodeling during hypertension by promoting basilar smooth muscle cell proliferation. Circulation 125, $697-707$

41. Kunzelmann, K., Nilius, B., Owsianik, G., Schreiber, R., Ousingsawat, J., Sirianant, L., Wanitchakool, P., Bevers, E. M., and Heemskerk, J. W. (2014) Molecular functions of anoctamin 6 (TMEM16F): a chloride channel, cation channel, or phospholipid scramblase? Pflugers Arch. 466, 407-414

42. Shimizu, T., Iehara, T., Sato, K., Fujii, T., Sakai, H., and Okada, Y. (2013) TMEM16F is a component of a $\mathrm{Ca}^{2+}$-activated $\mathrm{Cl}^{-}$channel but not a volume-sensitive outwardly rectifying $\mathrm{Cl}^{-}$channel. Am.J. Physiol. Cell Physiol. 304, C748-C759

43. Harper, M. T., Londoño, J. E., Quick, K., Londoño, J. C., Flockerzi, V., Philipp, S. E., Birnbaumer, L., Freichel, M., and Poole, A. W. (2013) Transient receptor potential channels function as a coincidence signal detector mediating phosphatidylserine exposure. Sci. Signal. 6, ra50

44. Van Kruchten, R., Braun, A., Feijge, M. A., Kuijpers, M. J., Rivera-Galdos, R., Kraft, P., Stoll, G., Kleinschnitz, C., Bevers, E. M., Nieswandt, B., and Heemskerk, J. W. (2012) Antithrombotic potential of blockers of store-operated calcium channels in platelets. Arterioscler. Thromb. Vasc. Biol. 32, 1717-1723

45. Scudieri, P., Caci, E., Venturini, A., Sondo, E., Pianigiani, G., Marchetti, C., Ravazzolo, R., Pagani, F., and Galietta, L. J. (2015) Ion channel and lipid scramblase activity associated with expression of TMEM16F/ANO6 isoforms. J. Physiol. 593, 3829-3848

Received for publication August 30, 2015. Accepted for publication October 5, 2015. 